\title{
A multidimensional time use and well-being index: a proposal for Colombia, Ecuador, Mexico and Uruguay
}

\author{
Evelyn Benvin, Elizabeth Rivera and Varinia Tromben
}

ABSTRACT

This article aims to develop a multidimensional index by integrating time use and well-being dimensions and proposes a conceptual framework based on the assets and the human capabilities approaches. The components of the index identify deprivations, which are understood to be barriers to the development of human capabilities and social justice. The optimum objective is to look beyond monetary metrics when identifying indicators that can better explain how the population, rather than the economy, is progressing and being guided by the principles of distributive justice. This study implements the AlkireFoster identification and aggregation method (2007 and 2013) and shows the results for four Latin American countries (Colombia, Ecuador, Mexico and Uruguay), using time-use surveys and distinguishing by household type.

KEYWORDS

JEL CLASSIFICATION

AUTHORS
Social welfare, women's employment, equal pay, social indicators, time use statistics, Colombia, Ecuador, Mexico, Uruguay

I32, J16, J22, O54

Evelyn Benvin is an adviser at the National Children's Council in the Ministry General Secretariat of the Presidency of Chile. ebenvin@consejoinfancia.gob.cl or ebenvin@gmail.com

Elizabeth Rivera is an adviser at the National Children's Council in the Ministry General Secretariat of the Presidency of Chile. erivera@consejoinfancia.gob.cl or erivera@brandeis.edu

Varinia Tromben is an associate economic affairs officer in the Social Development Division of the Economic Commission for Latin America and the Caribbean (ECLAC). varinia.tromben@cepal.org 


\section{I}

\section{Introduction}

This article aims to develop a multidimensional index by integrating time use and well-being dimensions and proposes a conceptual framework based on the assets and the human capabilities approaches. The proposed index integrates normative and political aspects of the sexual division of labour, which is understood to be the unequal distribution of activities relating to unpaid work (UW) —including unpaid domestic and care work — and paid work (PW) between women and men. This requires taking a gender- and human-capabilities-based approach in conceptualizing, establishing and measuring "time poverty" and living conditions. First, the daily activities of an individual are identified (by grouping them under UW or PW). Second, minimum or maximum thresholds that an individual must reach in order to be classified as non-poor in terms of real time distribution are defined. Thresholds are also established to identify the population with deprivations in the other dimensions of the index.

Conceptually speaking, one challenge of this article is to explain the implications of treating time as an

$\square$ This article is an abridged version of the work carried out in 2014 by the Division for Gender Affairs of the Economic Commission for Latin America and the Caribbean (ECLAC), in the framework of the project "Promoting Equality in Latin America and the Caribbean," financed by the Ministry of Foreign Affairs of Norway. asset and to build these theoretical consequences into a multidimensional index from a human capabilities perspective that integrates time and living conditions. Another key challenge is to generate arguments in favour of using multidimensional indices on time use and living conditions as a way to complement income poverty indicators with a view to designing and tracking poverty reduction strategies. Such an index can contribute to public policies through monitoring policies related to unpaid care work, the family (family benefits), employment, transport, fiscal policy and other areas. It can also provide evidence of some of the barriers that women face in terms of their economic autonomy, as well as the lack of distributive justice within the household.

This article is structured as follows. Following the Introduction, which has offered an account of the rationale, relevance and objectives of the proposed multidimensional index on time use and living conditions, section II develops the conceptual aspects related to time use. Section III focuses on the methodology used to develop the index, that is, the unit of analysis, and introductory dimensions and notions regarding the definition of the established thresholds. Section IV presents the results of the index using time-use surveys for Colombia, Ecuador, Mexico and Uruguay. Lastly, section $\mathrm{V}$ offers some final reflections on the potential and limitations of this index.

\section{II}

\section{Why does time matter for well-being and the development of human capabilities?}

\section{Time as a key aspect of well-being}

Well-being is a multidimensional concept that involves both tangible and intangible factors. Time, one of the intangible factors, refers to an individual's freedom and opportunities to allocate his or her time to the activities he or she considers to be essential for his or her wellbeing and capacity-building (Robeyns, 2003). In this regard, time is a high-impact resource for the creation and accumulation of assets and other resources; and restrictions on time ${ }^{1}$ represent barriers to the conversion of capabilities ${ }^{2}$ into effective functionings. These restrictions

\footnotetext{
1 Restrictions such as the sexual division of labor and the monopoly of power in household decision-making.

2 The concepts of capabilities and functionings are defined later.
} 
come from social, cultural and historical constructs that have effects at the individual, the household and the social levels ${ }^{3}$ (Carrasco, Borderías and Torns, 2011). "Time poverty" is thus understood as a restriction on an individual's freedom and opportunity to establish the amount of time to devote to the activities that he or she values, with negative impacts on his or her present and future well-beings.

Time poverty, arising from the excessive burden demanded by paid work, can negatively affect the wellbeing of a household, because it restricts the time that can be devoted to unpaid domestic work and care of dependent household members (Robeyns, 2003). However, the opposite can also be argued: an overburden of unpaid work is what generates "time poverty", especially given the unequal distribution between men and women. This situation affects mainly those who usually bear the largest share of domestic work-women.

The vulnerability caused by time poverty has differentiated effects depending on the time constraints it places on an individual, who must rely on his or her own characteristics and capabilities to cope with the limitations arising from time deprivations (Ballet and others, 2014). In other words, an individual's degree of vulnerability is part of his or her heterogeneous responses to time poverty and the way it restricts individual and family well-being. Bittman and others (2005) emphasize the link between time poverty and social exclusion, which is an inverse relationship insofar as a smaller allotment of free time can increase social exclusion.

A different current of thought may argue that the gender inequalities caused by the sexual division of labour have an unclear impact on well-being, given that women's overburden of domestic work in the household could arise from a free, informed and consensual decision among the members of the household. This overburden may represent the highest value activity among those from which an individual has the opportunity and freedom to choose. In this case, the overburden of paid work may not imply a constraint of the factors of transformation of capabilities into effective functionings and thus may not harm individual well-being. ${ }^{4}$ However, in this study this is considered to be a conservative interpretation of the capabilities approach, because it assumes that an

\footnotetext{
3 Specifically, in time allocation, an individual interacts with the factors involved in the process of transforming individual capabilities into functionings.

4 An extensive body of literature exists on feminist economics' critiques of the "new economy of the family." This may be reviewed in Carrasco (1991).
}

individual's well-beings will not be affected when he or she makes free and informed decisions based on his or her individual preferences. Even when decisions are free and informed, individual decisions may be highly influenced by cultural norms and social expectations regarding traditional gender roles and the sexual division of labour, which confine women to the private sphere and exclude or discourage them from participating in the public world.

\section{Time as a resource}

In the 1970 s, most of the conceptual discussion on time poverty defined time as a "resource." Vickery (1977) and Gronau (1977) defined time in their models as a resource that can be used for production activities in the market, as unpaid work in the form of unpaid care work within the household or invested in personal leisure and rest. Time considered an asset is a particular kind of asset, because it is a fixed resource that is egalitarian for the entire population (Goodin and others, 2008). Although time and income differ in this regard, Johnstone (1960) argued that they have the same problem: how can they be efficiently and successfully allotted on a day-to-day basis in accordance with the preferences of each person or household? This question must be understood in a context in which most of the population has limited time and income that must be distributed among a variety of spending and investment needs and alternatives.

Bardasi and Wodon (2009) suggest that, unlike with income, assigning more time to an activity is not always better. Given that time is a limited resource, assigning more of it to paid or unpaid work necessarily means devoting less of it to leisure and entertainment, which could heighten time poverty. Conversely, if an individual sacrifices consumption of certain basic goods in order to be able to afford other basic goods, the utility function remains unchanged; hence, this change would not be considered to impact negatively on an individual's well-being.

Conservation of resources theory defines resources as personal characteristics, conditions, or energies that are valued by the individual or that serve as a means for the attainment of other resources (Hobfoll, 1989, cited in Adkins and Premeaux, 2012). This definition treats time as an important resource for individuals who value it. This could generate an analytical gap between time and income, because income is generally assumed to be highly valued while this may not necessarily be the case for time. Accordingly, it is important to recall that individuals do not value all resources equally, and that 
personal preferences and sociocultural factors play a role in this appreciation.

Conservation of resources theory and its link with (deprivation of) time use implies that, as with income, the marginal benefit of each minute or hour depends on the level (or intensity) of use of the resource time. In other words, even if time per se represents a deprivation, the quality of the remaining or unused time that can potentially be distributed among different activities is a factor that a poverty indicator would have to consider. Burchardt (2010) notes that the yield of time use varies among the population, depending on individual income. For example, an hour in the time of a worker in the upper income deciles can be exchanged for one of many activities. However, the options are more limited for workers in the lower income deciles, since this segment of the population has fewer options for procuring services in the market to broaden their opportunities beyond domestic work.

However, whether or not time is treated as a resource does not prevent its conceptualization as a facilitator of or a barrier to "capabilities" and its potential effects on well-being.

\section{Time as a facilitator of or a barrier to human capabilities}

The concept of capabilities ${ }^{5}$ refers to the set of vectors of functionings or "beings" and "doings" that encapsulates an individual's freedom to lead the type of life he or she considers worthwhile (Sen, 2000). Treating time as a factor that, given the freedom and opportunities, ${ }^{6}$ facilitates the transformation of capabilities into effective functionings $\mathrm{s}^{7}$ for paid and unpaid work implies that an individual's capabilities should be assessed not by the resources and assets he or she possesses, but by

\footnotetext{
5 Sen (1992 and 2000) and Nussbaum (2011) introduced the concept of capabilities in the study of social justice and freedoms, respectively. Sen's capability approach (1992 and 2000) is a "moral theoretical framework" which proposes that social structures must be appraised by the scope of freedom people have to pursue or attain the functionings they value. Another characteristic of the capabilities approach is the role of moral considerations and ethical principles, and the concern for justice, such that everyone can develop the capabilities they value in a context of equal opportunities for all within the "universe of capabilities" (Alkire, 2002).

6 In the capabilities approach, opportunities refer to functionings, which are defined as what an individual is capable of being or doing.

7 Robeyns (2003) establishes that the difference between functioning and capabilities is similar to the differences between achievements and the freedom to achieve, or the difference between results and opportunities. Capabilities together correspond to the freedom an individual has to achieve what he or she values (p. 63).
}

the effective exercise of freedom and opportunities to allocate his or her time among the activities he or she values. The allocation of time among the activities that an individual values is important because it is closely associated with his or her well-being (Stiglitz, Sen and Fitoussi, 2009) and is related to distributive justice.

The capabilities approach paves the way for a broader comprehension of inequality between the sexes than an approach based on the comparison of primary goods or resources (Sen, 2000). The distribution and allocation of time can be seen as the outcome of interrelating microinequalities, in the context of resource distribution and power use within a family unit. Brighouse and Robeyns (2010) thus argue that gender inequalities affect the access to opportunities to combat inequalities between caregivers and non-caregivers and the gender division within households. This argument adds further layers of complexity to the question of time poverty measurements or indicators, perhaps including the concepts of socioeconomic justice, freedom and individual agency.

According to Fraser and Honneth (2006) and Fraser (2009), claims for social justice divide into two types: distributive claims seeking a fairer distribution of resources and claims for recognition. Fraser (2009) integrates the two types in an approach that supports, from a normative and methodological perspective, the design of an indicator for public policy monitoring. ${ }^{8}$ For the purpose of this research, it is important to consider the different theoretical approaches to socioeconomic justice grounded in recognition. This helps to answer the following questions: how can claims for socioeconomic justice in the (re)distribution of time between PW and UW be resolved? In what context or at what level —individual or collective - do the two approaches to socioeconomic justice (recognition and resource distribution) interact? How is justice served through recognition and how is it complemented by resource distribution?

One of the aims of analysing time as a facilitator or barrier to human capabilities individually and within the household is to help change patterns of time distribution that are based on inequality and the absence of freedom and distributive justice.

In keeping with this idea, time poverty represents a restriction on beings and doings and reflects a lack of access to capabilities. Sen (1992 and 2000) emphasizes the complementarities between an individual's different capabilities and his or her reliance on the characteristics of others and of the settings in which they live, including

\footnotetext{
8 Public policies aimed at achieving redistribution of resources and recognition in pursuit of greater social justice.
} 
justice. Although they have an intrinsic value, many of these capabilities are also a means to expand other capabilities that serve to increase well-being.

Conversion or transformation factors are also societal and, as argued by Brighouse and Robeyns (2010), this is the aspect of the capabilities approach that supports the argument for eliminating inequalities between men and women, because they affect women's capabilities to transform means or resources into functionings.

From the human capabilities and the gender approaches, time poverty must be conceptualized at the individual, the intra-household and, thus, the relational levels in terms of the preferences, restrictions, freedoms and opportunities that an individual has at the moment of time allocation. That allocation may or may not lead to time deprivation for an individual or other household members. For example, an individual may not lack time if another member of the household has transferred part of his or her time, sacrificing his or her own well-being (or not). Consequently, this transfer may be considered intra-household solidarity.

Recognition of time, as a resource that can be affected by conversion factors (internal in relation to the individual, social or within the household), is closely related to the recognition of unpaid caregiving, paid work and leisure as capabilities. Time is a resource and a means that, together with factors of conversion, throws into stark relief the influence of the sexual division of labour and the expectations and social norms associated with it and, hence, the "agency" that individuals have to make decisions that differ from social expectations. There is, of course, no such thing as a definitive list of human capabilities. Sen (1992) leaves the definition of capabilities open and insists that they should be defined among different voices, with sensitivity to gender differences, because it would be harmful not to consider these differences. Nussbaum (2003) proposes a list of basic capabilities for human development, among which a necessarily universal capability is receiving and giving care.

Level of individual agency (Sen, 2000) and lack of income autonomy are causes and effects, or both, of the interaction between time poverty and inequalities at the personal, family and social levels. An important assumption in the study of time poverty is that individuals with greater agency are less likely to be time-poor, either temporarily or permanently. Sen (2000) defines agency in terms of "someone who acts and brings about change, and whose achievements can be judged in terms of her own values and objectives." Consistently with the capabilities approach, Pick and Sirkin (2010) propose the concept of agency as one that assumes more freedoms and responsibilities, increasing the sense of personal investment in development. These authors also describe agency as a concept that requires behaviours and decisions from individuals who do not perform according to external expectation and evaluation. Consequently, in a context of unequal time distribution, an individual with weaker agency is likely to be more time-poor than an individual who has stronger agency and is thus able to delink decisions from external expectations and assessments. It may be asked whether this act of delinking is a requirement or necessary condition for the use of capabilities - in Sen's terms - and for the exercise of agency.

Where external restrictions or structural barriers result in the absence of justice, an individual is not in a position to exercise economic autonomy. Lack of economic autonomy represents a deprivation of freedom when a person cannot, for example, devote time to PW, because UW restricts the distribution of time use. Consequently, uw becomes a barrier to entry to $\mathrm{PW}$ and the exercise of freedom. When an individual cannot exercise agency and freedom, the factors that limit his or her real possibilities of overcoming time poverty become more powerful. ECLAC views economic autonomy, freedom and socioeconomic justice as core components of individual and social well-being (ECLAC, 2014). Economic autonomy is a manifestation of the capability to exercise individual agency in the distribution of time among activities that contribute to well-being. The concept of freedom is one of the normative notions regarding the preconditions that have the potential to ensure that an individual may exercise agency.

\section{Time poverty: remarks and assumptions regarding its definition}

The concept of time poverty has been developed more empirically than theoretically. Rather than a comprehensive theory on time poverty, what exists is a set of assumptions that are still in the process of being defined. These are identified below.

In general terms, the poor population is identified on the basis of socioeconomic conditions that are considered to be unacceptable in a given society. Poverty has been conceptualized, on the one hand, as deprivations in terms of access to goods, services and income necessary to support a level of well-being accepted as a minimum in a society; and, on the other hand, as an unacceptable degree of inequity in social arrangements (Sen, 1992). 
The conceptual development of time poverty integrates notions of equality, equity, distribution, freedom and recognition of injustices within the household. These are all notions that, together, are considered factors that explain part of the time allocation among activities that individuals value. The identification of deprivations - associated with inequity within the household and in the labour market - is one of the contributions of feminism, which emphasizes the effects of the sexual division of labour and women's excessive work burden on time poverty. Women — besides engaging in paid workcontribute most of the UW in households (ECLAC, 2013c).

The first assumption, the most common in the literature on time poverty, is the consideration of time as a resource, along with the negative influence that an individual's lack of freedom and agency exerts on time distribution. This distribution is markedly influenced by the unequal division of labour between women and men, and by the low social and economic value attributed to unpaid work compared with paid work (Jain, 2013, cited in ECLAC, 2013c).

A second assumption has to do with the trade-off between PW and UW at the individual and social levels. It may be asked whether this applies to men and women alike, or may be applied rather to those who value PW and Uw equally. The existence of this trade-off is also called into doubt by the question of whether the tradeoff is between time and income.

A third assumption is that an individual with less power within the household (Chiappori and others, 2011), weaker agency (Pick and Sirkin, 2010), and less influence over household spending decisions (Bonke and Browning, 2003) is the one who allocates a larger portion of his or her time to Uw. Consequently, those factors restrict equitable allocation of uw time between the members of the household. Restrictions associated with lack of freedom in time allocation have effects for the population's living standards and income.

The allocation of time to PW potentially generates resources to meet the needs of individuals and their families and enables them to attain economic autonomy. Time poverty affects the well-being of the population in a different manner, depending on economic status. Thus, time poverty makes households that are not income-poor vulnerable, or more vulnerable. For example, individuals employed in lower-productivity and lower-income sectors are more likely to assign more time to PW, than their peers, in an attempt to make up for their low wages. As a result, employed individuals have fewer hours to devote to UW and leisure, to the detriment of family and household well-being.

The fourth assumption is that time poverty is a restriction on family well-being and on personal human development. Vickery (1977) and Goodin and others (2008) argue that a household needs enough time, as well as income, to maintain a minimum level of production to ensure its well-being. This is a basic premise among time poverty metrics, on the understanding that an individual and his or her household need more than income alone to function properly. Specifically, viewed in terms of the empirical development of well-being indicators, this assumption refers to a positive balance between family and work, among other quality-of-life criteria.

The fifth assumption concerns inequality in the free allocation of time among income groups in the population. The lower-income strata find it more difficult to substitute UW for market consumption of domestic labour and mercantilized care. Workers in these strata are highly likely to have an excessive total work burden (total time spent on PW and UW) and to become time-poor, as well as to belong to the income-vulnerable group. Lower-income individuals may, for example, receive time transfers to offset their lack of access to market care services, which can ease their time deprivation. For this reason, surveys and household survey modules on time use must include questions aimed at identifying the origin and destination of UW delivered outside the household of its providers.

The sixth assumption is linked to the very heterogeneous needs that household have in order to function. These needs arise from the cycles they experience in the production of unpaid domestic and care work, depending on their composition (number of dependants: children and older persons) and stages of life of their members (Douthitt, 1994). The study of Uw focuses on the allocation of time to unpaid care and domestic work and its core questions in relation to time poverty and household life cycles include: what is the minimum amount of time that must be allocated to Uw for a household to function at different stages of the family life cycle? What is the smallest relative contribution to Uw that an individual can make in the household without impinging upon another household member's allocation of time to PW and leisure?

Unlike poverty measurements based on basic needs, time poverty is not only based on the notion of access to social minimums, but also emphasizes the lack of control over, or freedom to use, resources - in this case time and 
income - or assets in pursuing the satisfaction of material needs (Goodin and others, 2008, and Gammage, 2009). Conversely, traditional poverty measurements offer an approach to material deprivations or shortfalls in living standards, represented by a shortage or the precariousness of resources, goods or access to public services (Feres and Mancero, 2001). This latter approach to poverty is part of the conceptual framework that treats income and material goods as the main proxies of well-being.

A key question for poverty measurement and analysis is: can an individual or household be considered poor if their time allocation decisions lead to a higher level of economic well-being contingent on a greater deprivation of time? There are probably different answers to this question, but they would be limited if the arguments were informed only by one-dimensional time poverty indicators. It may be methodologically challenging to answer this question by means of indicators that use other variables in addition to time, but it is also necessary in order to arrive at a better understanding of poverty and its manifestations.

Durán (2007) adds that individual time poverty is more temporary than structural, inasmuch as the life cycle of individuals and their households determines most of time poverty. This is to assume that, once dependent children who are in need of direct care move to a stage of indirect care, parents can free up, in an equitable manner, the time they previously devoted to direct caregiving. Understanding that this example is determined largely by gender roles, Durán (2007) shows the importance of shedding light on how these roles establish time distribution between women and men. How close or far individual decisions and behaviours are to these roles partly determines the freedom and flexibility to allocate time between PW, UW, personal activities and leisure time. A time poverty indicator could be said to represent the notion of distributive justice, insofar as it recognizes that the reinforcement in time allocation has to do with gender roles that affect choices among potential alternative functionings and adjust them to social expectations. The emphasis, as well as an advantage, of developing a definition of time poverty from the gender and the capability approaches is that if an individual is time-deprived, this may be understood as a restriction on the freedom to choose between different combinations of activities that impact on time allocation, which could undermine individual well-being.

The majority of time poverty indices have shown gaps, trends or changes in the phenomena they study and have specifically measured functionings or outcomes rather than capabilities. For example, absence of the capability for healthy living and good nutrition is treated the same, whether the individual lacks the capability for healthy living and good nutrition or fasts by his or her own free and informed decision and preference. This example applied to time poverty as a restriction on capabilities, indicates the complexity of identifying an individual as time-poor without knowing his or her preferences or at least intention in an imaginary scenario of time distribution change. This considers the challenge of including questions on preferences and expectations regarding the current and future redistribution of time use by the population.

Time poverty measurements can be grouped into one-dimensional and two-dimensional measurements. The main objective of one-dimensional studies is to identify an individual's time deficit after the chronological allocation of his or her PW and UW activities and how this relates to income poverty in the population deprived of discretionary time (Goodin and others, 2008). Conversely, two-dimensional time poverty studies aim to identify the population whose poverty status is conditional on their shortages of time and income (Zacharias, 2011). This study supports the idea that two-dimensional time-income poverty measurements suffer from a major limitation: the gender perspective is confined to the disaggregation of the indices by sex. For this reason, two-dimensional timeincome poverty measurements are constrained in terms of enabling a deeper understanding of the inequalities and injustice regarding recognition and valuation of women's contribution to unpaid work in the household.

The following section develops a multidimensional index using the assumptions identified in the literature on time poverty. The dimensions of the index are treated as "spaces" in which individuals can exercise their freedom and agency in the distribution of time between PW and UW. Of the conceptual frameworks reviewed in this section, the capabilities approach helps to show how a multidimensional index can reveal barriers at the individual and the household levels that reduce the freedom and equity of its members, and determine the cases in which the distribution of time use is a matter of injustice. At the same time, using the concept of justice in the framework of the human capabilities approach implies that justice and its approach through the development of a multidimensional index must be sensitive to the ability of individuals to transform their capabilities into effective functionings. 


\section{III}

\section{Methodology of the well-being index}

\section{Description of the data: time-use surveys}

The data sources are time-use surveys conducted in four countries in the region: Colombia (2012), Ecuador (2012), Mexico (2009) and Uruguay (2007). These surveys correspond to those available at the time of the research. Table 1 summarizes the methodological information relating to these surveys.

Women work more than men: on average in the four countries, total work time is 45.9 hours per week for men, and 52.5 hours per week for women (see figure
1). Analysing work by type reveals the sexual division: women carry an Uw burden three times that of men. The level of Uw (unpaid care and domestic work) is also uneven for women but even for men, after controlling for level of education, income, civil status, dependants in the household, activity status and age.

Life cycle is another important element in the analysis: men and women both work most during the 25 to 45 age range. This is also the age group in which the gaps between men and women are the largest (see figure 2).

TABLE 1

\section{Description of time-use surveys}

\begin{tabular}{|c|c|c|c|c|}
\hline Country/year & Purpose and universe & Classifier & $\begin{array}{l}\text { Sample size and } \\
\text { coverage }\end{array}$ & Methodological aspects \\
\hline Colombia (2012) & $\begin{array}{l}\text { To generate information regarding the time } \\
\text { that the population aged } 10 \text { years and older } \\
\text { devotes to work and personal activities. }\end{array}$ & $\begin{array}{l}\text { CAUTAL } \\
\text { ICATUS }\end{array}$ & $\begin{array}{l}46310 \text { households; } \\
\text { national coverage. }\end{array}$ & $\begin{array}{l}\text { List of activities during } \\
\text { the } 24 \text { hours prior to } \\
\text { the interview. }\end{array}$ \\
\hline Ecuador (2012) & $\begin{array}{l}\text { To generate information regarding the time } \\
\text { that individuals aged } 12 \text { years and over } \\
\text { distribute among paid activities, unpaid } \\
\text { activities and free time. }\end{array}$ & CAUTAL & $\begin{array}{l}23400 \text { households; } \\
\text { national coverage. }\end{array}$ & $\begin{array}{l}\text { List of activities during } \\
\text { the week. }\end{array}$ \\
\hline Mexico (2009) & $\begin{array}{l}\text { To measure the time individuals aged } 12 \\
\text { years and over devote to daily activities and } \\
\text { to provide statistical inputs necessary for } \\
\text { measuring all forms of work, including paid } \\
\text { and unpaid work. }\end{array}$ & $\begin{array}{l}\text { CMAUT } \\
\text { ICATUS }\end{array}$ & $\begin{array}{l}16925 \text { households; } \\
\text { national coverage. }\end{array}$ & $\begin{array}{l}\text { List of activities during } \\
\text { the week. }\end{array}$ \\
\hline Uruguay (2007) & $\begin{array}{l}\text { To provide information regarding } \\
\text { participation in unpaid activities and } \\
\text { different types of unpaid work, and the time } \\
\text { household members, both male and female, } \\
\text { aged } 14 \text { years and over, spend on } \\
\text { these activities. }\end{array}$ & ICATUS & $\begin{array}{l}4200 \text { households; } \\
\text { national coverage. }\end{array}$ & $\begin{array}{l}\text { List of activities during } \\
\text { the week. }\end{array}$ \\
\hline
\end{tabular}

Source: Prepared by the authors, on the basis of official information.

Note: CMAUT: Mexican Classification of Time-Use Activities; ICATUs: International Classification of Activities for Time Use Statistics; CaUtal: Classification of Time-Use Activities for Latin America. 
FIGURE 1

Colombia, Ecuador, Mexico and Uruguay: time spent on PW and UW, population aged 15 years and over and employed population

(Hours per week)

A. Population aged 15 years and over

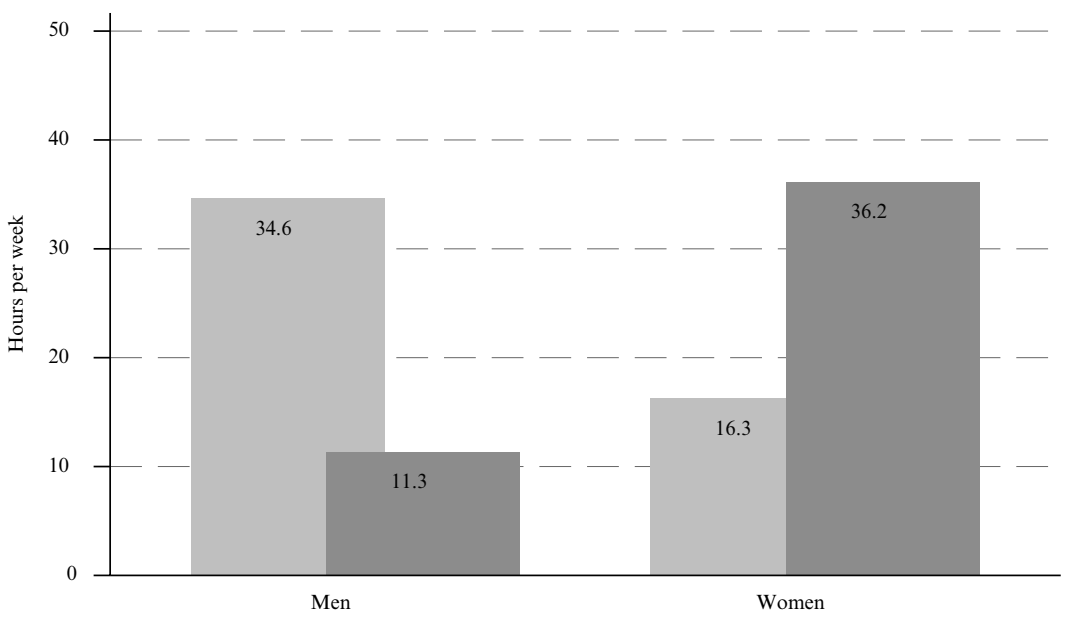

PW

B. Employed population

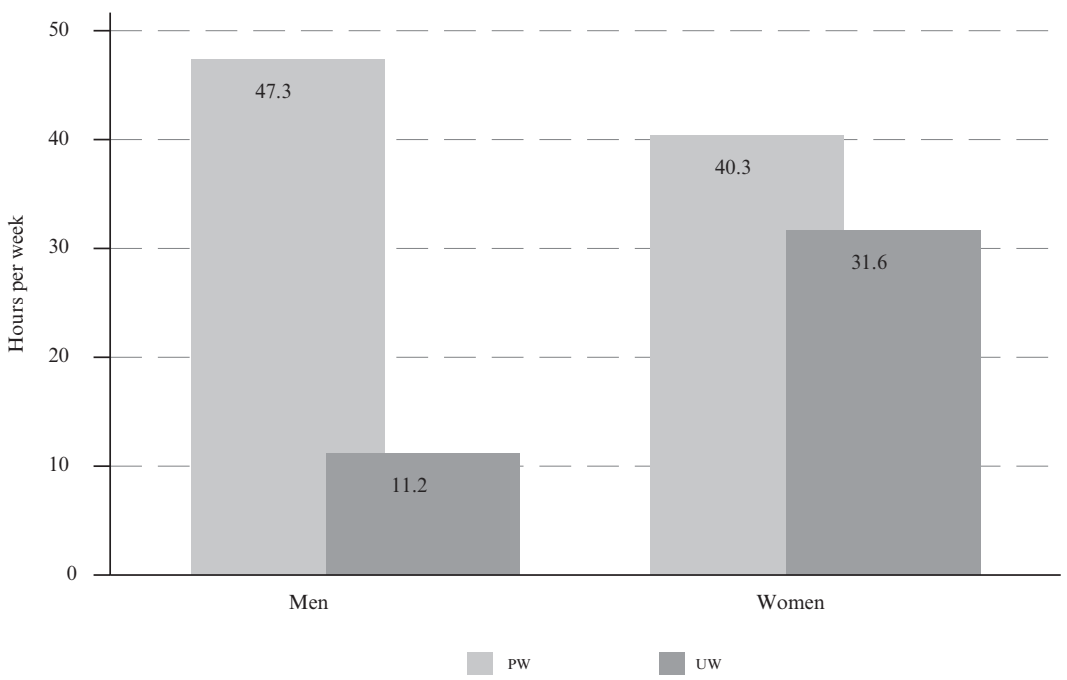

Source: Prepared by the authors, on the basis of special tabulations of data from time-use surveys from Colombia (2012), Ecuador (2012), Mexico (2009) and Uruguay (2007)

Note: Simple averages; Pw: Paid work; uw: Unpaid work. 
FIGURE 2

Colombia, Ecuador, Mexico and Uruguay: time devoted to PW and Uw by age group, population aged 15 years and over

(Hours per week)

A. Paid work (PW)
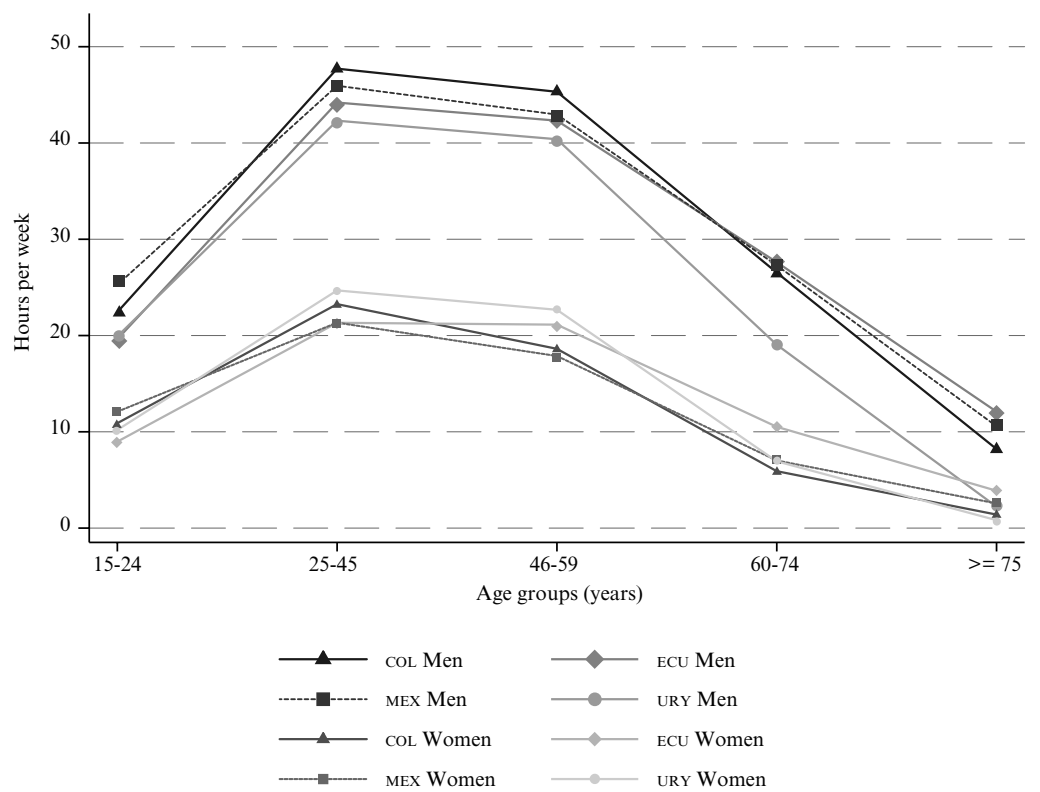

B. Unpaid work (UW)

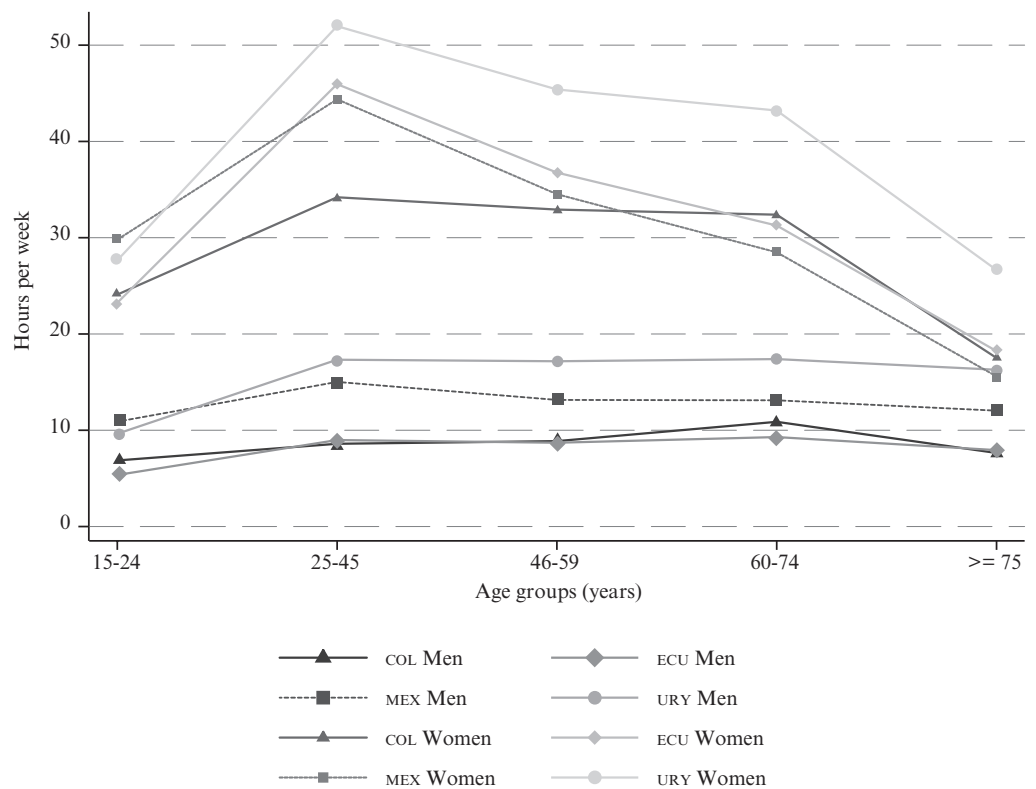

Source: Prepared by the authors, on the basis of special tabulations of data from time-use surveys from Colombia (2012), Ecuador (2012), Mexico (2009) and Uruguay (2007).

Note: COL: Colombia; ECU: Ecuador; MEX: Mexico; URY: Uruguay. 
These findings have been widely reported in different studies (see ECLAC, 2010a, 2010b and 2013c; Merino, 2010 and 2012). This article takes a step further in the analysis by looking within households and analysing how time devoted to UW is distributed among its members. Figure 3 shows the percentage of the contribution to UW made by men and women within the household. For the total population (left panel of figure 3.A), on average, the male figure in the household (male head of household or spouse) contributes $22 \%$ of the household's total UW, while the female figure (female head of household or spouse) contributes $57 \%$. The remainder (22\%) of the total Uw time performed in the household is carried out by other members (children, other family members or other adults). These proportions indicate small variations by activity status (centre and right panels of figure 3.A).
In the percentage contribution by type of household, the widest gap between men and women occurs in the case of two-parent households: while women contribute on average $64 \%$ of the household's UW, men contribute just $18 \%$ (centre panel of figure 3.B). In the case of composite and extended households (left panel of figure 3.B), men and women both make a smaller contribution, reflecting the greater contribution of other household members. Lastly, single-parent households (right panel of figure 3.B) are notably the only case in which men contribute more UW than women. ${ }^{9}$

${ }^{9}$ Only $11.3 \%$ of men are heads of single-parent households, compared with $31.4 \%$ of women.

Colombia, Ecuador, Mexico and Uruguay: contribution to household UW (Percentages)

A. By activity status
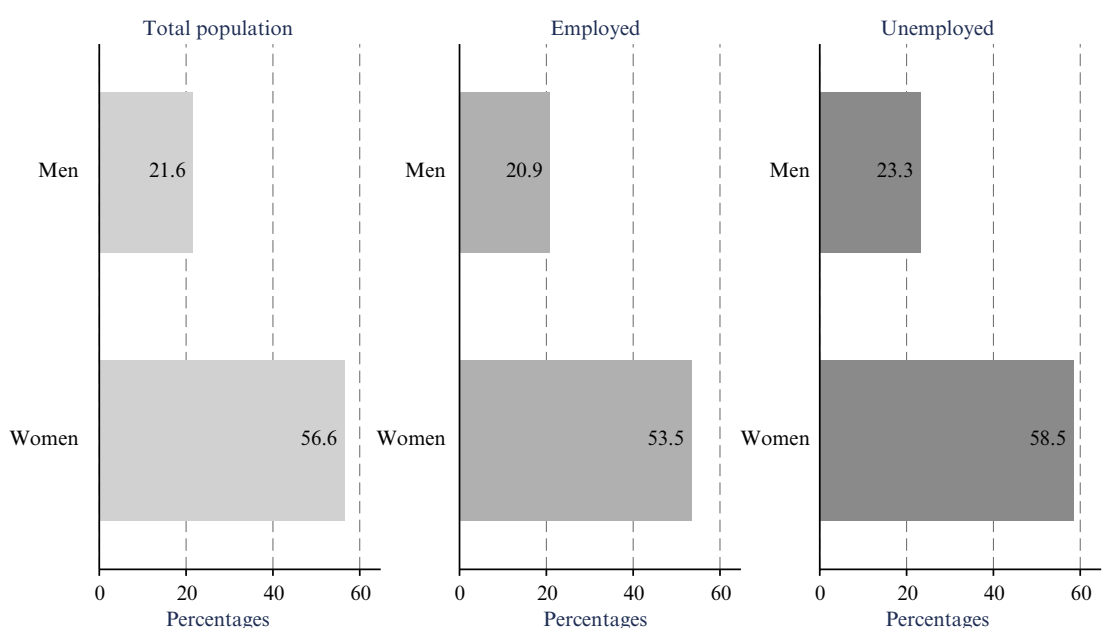
Figure 3 (concluded)

B. By type of household
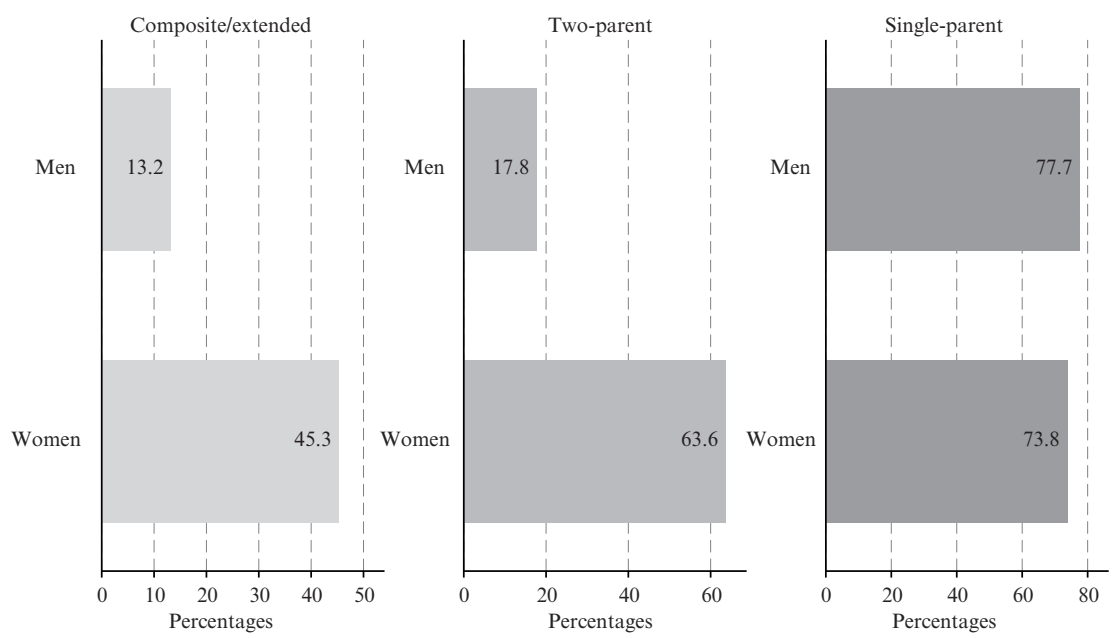

Source: Prepared by the authors, on the basis of special tabulations of data from time-use surveys from Colombia (2012), Ecuador (2012), Mexico (2009) and Uruguay (2007).

Note: Unpaid work (UW) refers to average hours per week spent on domestic work, unpaid care work and voluntary work. In the four surveys used, the interviews were administered to all household members over the ages of 10,12 or 14, depending on the country (see table 1).

\section{Defining the unit of analysis: the household}

Individuals share not only a roof and their income (regardless of how equally it is distributed), but also time and its distribution within the household. Individuals in multi-person households do not distribute their time independently of the other household members. A debate within contemporary feminism questions self-determination as a notion that establishes time distribution, insofar as self-determination is understood to be a relational and group-based notion. In other words, the idea of a man or a woman exercising self-determination after a process of reflection and prioritization of preferences is understood in the context of relations between individuals.

The inequalities between men and women regarding time distribution in PW and UW are considered not only from the gender perspective, but also in terms of the link to the composition and the structure of the household, and the individual and family life cycle. The overburden of PW and UW has a structural and time-bound component from the household perspective. Consequently, the analysis is conducted at the household level because the members have different capabilities that are interrelated with individual and relational decisions on time allocation and its distribution.

Defining the household as the unit of analysis means considering the interrelations among its members as key aspects regarding: the allocation, distribution and valuation of paid and unpaid work. This implies treating the household as a space in which economic activities are performed, and hence as an extension of the labour market.

This study also proposes an analysis by household type (size and composition), in order to shed light on demographic patterns that may affect multidimensional poverty measurements. It should be noted that taking the household as the unit of analysis does not result in the underestimation of time poverty and poor living conditions, since, by construction, individual multidimensional deprivation always depicts less poverty than household deprivation multidimensional measures (Díaz, 2013).

The remainder of this section analyses different types of households: (i) two-parent nuclear; (ii) single-parent; (iii) one-person; (iv) composite and extended with two parents (spouses and heads of household), and (v) other composite and extended. In all cases, persons (including their dependants) performing domestic work for pay were excluded from the calculations. For this research, the household types defined are based on those established by the United Nations Statistics Division, ${ }^{10}$ but slightly

10 See [online] http://unstats.un.org/unsd/demographic/sconcerns/ fam/fammethods.htm. 
modified: composite and extended households were grouped together, and separated into two subgroups by the presence or absence of a spouse in the household.

\section{Defining the dimensions and their indicators}

The proposed index has five dimensions: time use, living conditions, economic autonomy, education and social exclusion. The indicators most used in multidimensional poverty measures are those that capture deprivations in housing (overcrowding and precarious materials), in basic services (water, sanitation and energy) and in education, owing to their significance and the availability of information from the household surveys. This work follows the proposal by ECLAC (2013b) regarding these usual dimensions and adds others referring to time and economic autonomy. Table 2 set outs the dimensions, indicators and weightings that compose the multidimensional index.

The dimension "time use" is composed of two indicators: one for PW and the other for UW.

Indicator 1: time for Uw, which includes unpaid domestic and care work. The household is deprived if at least one of its members shows an individual contribution (in percentages) to total household Uw of less than $50 \%$ of the median (the median contribution per type of household) for the female population aged 15 years and over.

TABLE 2

Dimensions and indicators of deprivations and their weightings

\begin{tabular}{|c|c|c|}
\hline Variables & $\begin{array}{l}\text { Indicator of deprivation: the household is deprived in this dimension } \\
\text { if for at least one household member... }\end{array}$ & Weighting \\
\hline \multicolumn{3}{|l|}{ Dimension I: time } \\
\hline Time for unpaid work & $\begin{array}{l}\text { The individual percentage contribution to Uw (unpaid care + domestic work) } \\
\text { is less than } 50 \% \text { of the median contribution of women, by type of household. }\end{array}$ & $1 / 10$ \\
\hline Time for paid work & $\begin{array}{l}\text { The number of hours is greater than the weekly ceiling according } \\
\text { to national legislation. }\end{array}$ & $1 / 10$ \\
\hline \multicolumn{2}{|l|}{ Dimension II: living conditions } & $1 / 5$ \\
\hline $\begin{array}{l}\text { Lack of access to an improved } \\
\text { water source }\end{array}$ & $\begin{array}{l}\text { In urban areas: the water source is different from the public water system. } \\
\text { In rural areas: the water source is unprotected well, bottled water, mobile water } \\
\text { sources, stream, river, rainwater, other. }\end{array}$ & $1 / 30$ \\
\hline Lack of a waste disposal system & $\begin{array}{l}\text { The dwelling lacks a hygienic sewage disposal system or service connected to the } \\
\text { public sewerage system or a septic tank. }\end{array}$ & $1 / 30$ \\
\hline Lack of electrical power & The dwelling is without electricity. & $1 / 30$ \\
\hline Cooking fuel harmful to health & The household uses fuelwood, coal or waste for cooking fuel. & $1 / 30$ \\
\hline Precarious housing materials & $\begin{array}{l}\text { Most of the dwelling is made of precarious materials. } \\
\text { Most of the roof of the dwelling is made of precarious materials. } \\
\text { The dwelling has dirt flooring. }\end{array}$ & $1 / 30$ \\
\hline Overcrowding & There are three or more persons per room. & $1 / 30$ \\
\hline Dimension III: economic autonomy & & $1 / 5$ \\
\hline Labour income & The daily wage is less than twice the minimum daily wage (53.19 Mexican pesos) & $1 / 10$ \\
\hline Population without independent income & $\begin{array}{l}\text { At least one individual (except students aged } 15 \text { and over) in the household has no } \\
\text { independent income. }\end{array}$ & $1 / 10$ \\
\hline Dimension IV: education & & $1 / 5$ \\
\hline Non-attendance at school & $\begin{array}{l}\text { At least one child of school age ( } 6 \text { to } 17 \text { years) in the household does } \\
\text { not attend school }\end{array}$ & $1 / 10$ \\
\hline Adult educational lag & $\begin{array}{l}\text { At least one adult aged } 30 \text { or more in the household does not have a minimum } \\
\text { level of education. } \\
\text { Individuals aged } 30 \text { to } 59 \text { : have not completed primary education or have } \\
\text { no schooling. } \\
\text { Individuals aged } 60 \text { and over: have no education. }\end{array}$ & $1 / 10$ \\
\hline \multicolumn{2}{|c|}{ Dimension V: social exclusion or vulnerability } & $1 / 5$ \\
\hline $\begin{array}{l}\text { NEET (not in education, employment } \\
\text { or training) }\end{array}$ & $\begin{array}{l}\text { At least one adult aged } 18 \text { to } 29 \text { in the household is not working or in education } \\
\text { or training (unemployed }+ \text { inactive). }\end{array}$ & $1 / 10$ \\
\hline Access to health & $\begin{array}{l}\text { At least one individual in the household is without access to the national } \\
\text { health system. }\end{array}$ & $1 / 10$ \\
\hline
\end{tabular}

Source: Prepared by the authors. 
Including an indicator on time allocation for UW in a multidimensional well-being index is intended to shed light from a gender perspective on individual contributions to total household work related to unpaid caregiving and intrahousehold domestic work, because it identifies the sexual division of labour within the household. Consequently, the proposed indicator incorporates the gender perspective from its creation, and not through disaggregation by sex. Another argument in favour of this indicator is that it includes a component of social justice, because it distinguishes the individual contributions to unpaid care and domestic work made by the main adults in the household — spouses and heads of household - from those made by other household members. Statistical analysis of the components of this indicator shows that for each subthreshold - type of household - the cut-off point between deprived and non-deprived households should be $50 \%$ of the median time allocated to unpaid care and domestic work by women. It is, therefore, a relative threshold.

This indicator may contribute to identifying the population and the households that have fewer opportunities and gender inequality in the exercise of unpaid care work and UW capabilities.

Identifying a minimum allocation of time to UW is based on a real situation that represents one of the restrictions on women's development of capabilities and depends upon the disproportionate contribution of women to unpaid work (UN-Women, undated). In this context, identifying the sector of the population that is deprived in terms of UW is crucial for providing evidence of gender inequality within the household.
Subthresholds by type of UW (unpaid domestic and care work) and by household type are used to identify the differences between household types in terms of structure and potential distribution of UW among its members. Burchardt (2010) argues that in the case of domestic work, a minimum absolute time allocation can be established, based on the domestic needs of a household of a certain composition. However, this article does not use this type of indicator, because given the heterogeneity of household types — and even if thresholds could be identified for each type of household, depending on its composition- defining an absolute threshold would require an extensive discussion and agreement on the minimum amount of UW that households need in order to function.

For example, in the case of Mexico, for illustration purposes, in nuclear two-parent households, $51.7 \%$ have at least one individual with deprivations associated with unpaid care and domestic work (see table 3). A household is considered deprived if it meets at least one of the following conditions: (i) the head of household contributes less than $38.5 \%$ of the domestic work and less than $24.1 \%$ of care work, considering the total time allocated to these two components of unpaid work in the household, or (ii) the other members of the household ${ }^{11}$ contribute less than $8.2 \%$ and $9.3 \%$ of the total time assigned in the household to domestic and care work, respectively.

11 That is, household members other than the head of household or spouse, excluding dependants over 80 years of age.

Mexico: value of subthresholds by household type and intrahousehold groups, and count of deprived households by indicator 1

\begin{tabular}{|c|c|c|c|c|}
\hline Household type & Groups within the household & $\begin{array}{l}\text { Cut-off point for } \\
\text { individual percentage } \\
\text { contribution to } \\
\text { domestic work }\end{array}$ & $\begin{array}{l}\text { Cut-off point for } \\
\text { individual percentage } \\
\text { contribution to } \\
\text { care work }\end{array}$ & $\begin{array}{c}\text { Households deprived } \\
\text { in both components } \\
\text { of the indicator }\end{array}$ \\
\hline One-person & Head of household and/or spouse & 50.0 & $\ldots$ & 3.3 \\
\hline \multirow[t]{2}{*}{ Composite or extended } & Head of household and/or spouse & 24.6 & 11.4 & 67.5 \\
\hline & Other household members & 10.7 & 10.0 & \\
\hline \multirow[t]{2}{*}{ Two-parent } & Head of household and/or spouse & 38.5 & 24.1 & 51.7 \\
\hline & Other household members & 8.2 & 9.3 & \\
\hline \multirow[t]{2}{*}{ Single-parent } & Head of household and/or spouse & 40.5 & 25.0 & 25.1 \\
\hline & Other household members & 14.1 & 16.1 & \\
\hline \multirow{2}{*}{$\begin{array}{l}\text { Composite or extended } \\
\text { without spouse }\end{array}$} & Head of household and/or spouse & 23.5 & 10.0 & 47.0 \\
\hline & Other household members & 15.5 & 13.9 & \\
\hline
\end{tabular}

Source: Prepared by the authors, on the basis of tabulations of data from the survey on time use (EUT) of Mexico, 2009. 
Indicator 2: time deprivation in relation to excess or overburden of $\mathrm{PW}$, in accordance with national legislation. A household is considered deprived if at least one of its members spends a total number of hours on PW greater than the maximum PW time established in national legislation.

Before defining this normative threshold, several relative cut-off points were tested based on the statistical distribution of the data of the relevant population. Accordingly, the median time of PW of employed persons aged 15 years and over was estimated, and $75 \%$ of this median was taken as the minimum threshold of time to be devoted to PW.

This indicator defines PW time deprivation in normative terms: a household is considered time-deprived owing to an excessive PW burden if at least one of its members allocates more than the weekly hours allowed in the national legislation to this purpose. An overburden of PW, according to Mexican legislation, means that an employed person works more than 57 hours per week (ILO, 2013). So, if at least one of the main adults or non-dependent adults in a household works more than 11.4 hours per day on average, that household will be time-deprived. Notably, $52 \%$ of the individuals who were PW time-deprived were also deprived in relation to UW.

A key question concerns the proportion of paid workers working more than the legal maximum hours and receiving labour income of two minimum wages or less (this being one of the indicators of the dimension "economic autonomy"). In the case of Mexico, $38 \%$ of the employed population works hours in excess of the legal maximum and earns two minimum wages or less. This shows the situation of the employed in terms of income and PW time as rather different from that portrayed in the literature, which focuses on the long work hours of high-income workers (Warren, 2003). On the contrary, this $38 \%$ of the employed wage-earning population works long hours for earnings that are insufficient to reach the middle of the income distribution of the employed population.

A possible alternative threshold is to consider the households in which at least one of the employed members (aged 15 years or over) works a total number of hours less than $75 \%$ of the median PW hours of the employed as deprived. Using a cut-off point of $100 \%$ of the median doubles the percentage of individuals with this deprivation. This alternative threshold was discarded, because in the process of presentation and discussion of this indicator it was difficult to agree on the policy implications of a poverty indicator for PW based on a minimum.

The development of the rest of the components of the multidimensional index was based on chapter I of the Social Panorama of Latin America 2013 (ECLAC, 2013b), in which multidimensional poverty was constructed on the basis of six dimensions (water and sanitation, energy, housing, education, income and exclusion). The proposal here follows this model with two exceptions. First, all aspects related to housing —water, sanitation, energy, materials and overcrowding — are grouped into a single dimension. Second, income is analysed as a function of the concept of economic autonomy, defined as "women's capacity to generate income and personal financial resources, based on access to paid work under conditions of equality with men. This parameter takes into account time use and women's contribution to the economy." This encompasses a more general concept of freedom, a fundamental factor in ensuring women's human rights in a context of full equality. It is crucial to identify households in which at least one member (excluding dependants) is deprived of economic autonomy, because this brings in a key dimension for the potential development of other capabilities. Part of the objective of this dimension is to show that, below a minimum level of economic autonomy, an individual is likely to find it difficult to develop other capabilities because of the limitations inherent in deprivation of economic independence.

The dimension "economic autonomy" includes two indicators:

Indicator 1: labour income. A household is considered deprived if at least one of its members has a daily wage of less than twice the legal minimum daily wage (in the case of Mexico: 53.19 Mexican pesos). ${ }^{12}$

Indicator 2: population without economic autonomy. A household is considered deprived if at least one mature individual (aged 30 years or more) - excluding students and dependants aged over 80 and the permanently disabled - has no independent income from paid work.

12 The amount corresponds to the average minimum daily wage in the year 2009 (information from the Secretariat of Labour and Social Security). 


\section{IV}

\section{Results of the multidimensional index components: incidence, intensity and $M_{0}$}

The results for the multidimensional time and living conditions index for Colombia (2012), Ecuador (2012), Mexico (2009) and Uruguay (2007) are presented below.

Figure 4 shows the gross household count per indicator. In the dimension of time: between $45 \%$ (in Mexico) and 65\% (in Colombia) of households are deprived in the indicator for $\mathrm{UW}$. With respect to the $\mathrm{PW}$ indicator, the count fluctuates between 19\% (Colombia) and $34 \%$ (Uruguay) of households. In the four countries, the smallest percentage of deprived households occurs in the dimensions associated with housing conditions (except sanitation), and non-attendance at school. The high gross counts for economic autonomy in all the countries are notable.

FIGURE 4

\section{Gross household count rate per deprivation indicator}

(Percentages of households)

\section{A. Colombia}

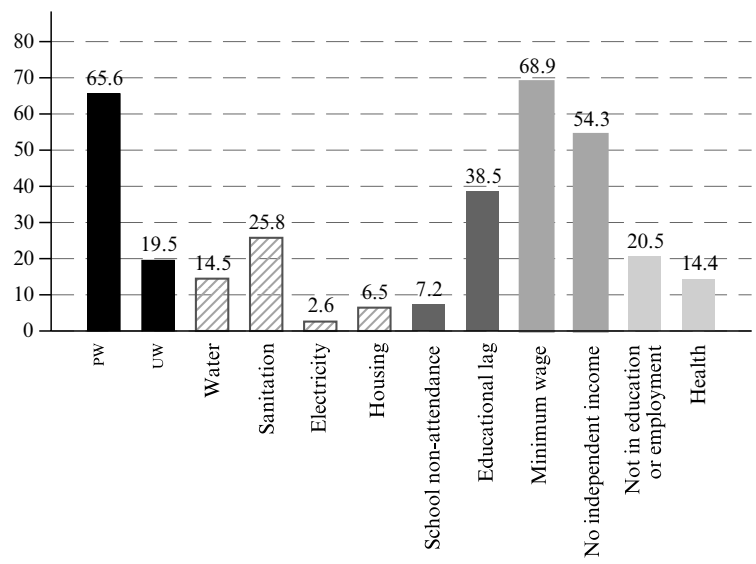

C. Mexico

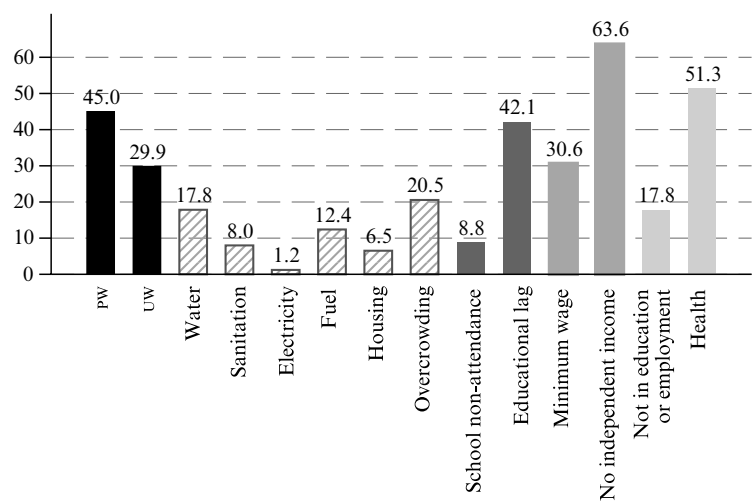

B. Ecuador

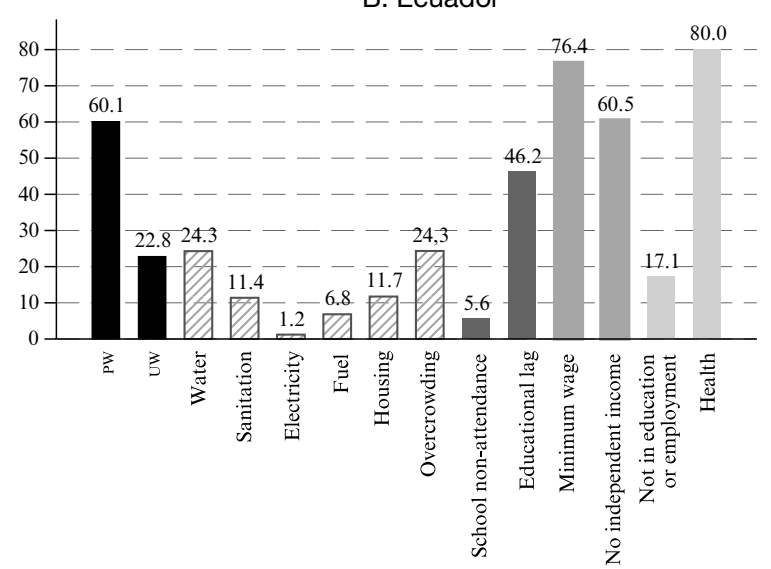

D. Uruguay

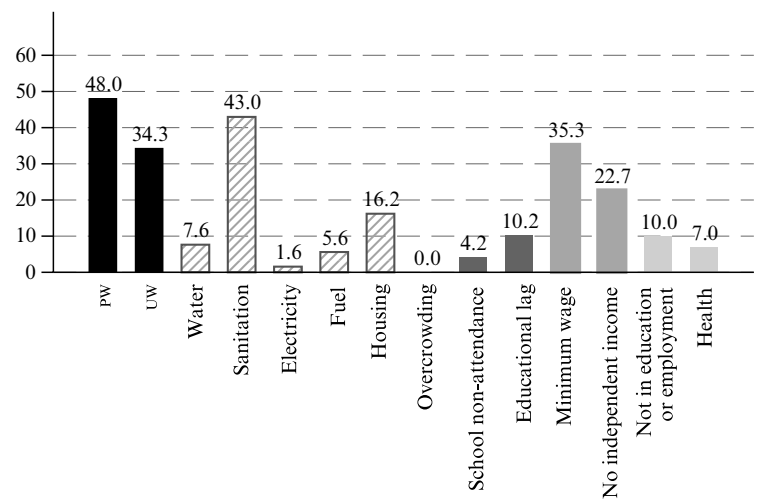

Source: Prepared by the authors, on the basis of tabulations of data from time-use surveys of Colombia (2012), Ecuador (2012), Mexico (2009) and Uruguay (2007).

Note: PW: Paid work; uw: Unpaid work. 
The household count rate ( $\mathrm{H}$ or incidence) of poor households falls substantially as the number of deprivations included rises (estimated cut-off point or $k$ considered a threshold of deprivation distinguishing between multidimensional poor and non-poor). Figure 5 shows that between $80 \%$ and $98 \%$ of households have deprivations of at least $10 \%$. Lastly, with a multidimensional threshold $(k)$ equivalent to $30 \%$ of deprivations, the multidimensional household count rate varies between 25\% (in Uruguay) and $78 \%$ (in Ecuador) of households (see figure 5, left panel). For these households, the average deprivation varies between $35 \%$ and $45 \%$ (figure 6, right panel). Figure 6 shows the results for $\mathrm{M}_{0},{ }^{13}$ according to the

13 The Alkire and Foster methodology (2007) defines multidimensional poverty of the adjusted headcount ratio as: $M_{0}=H^{*} A$. different $k$ values. The rest of the article analyses the results for $k=30 \%$.

One of the most useful properties of the Alkire and Foster (2007) multidimensional poverty methodology, from the point of view of public policy, is its decomposability. ${ }^{14}$ The largest contributions to the multidimensional index $\left(\mathrm{M}_{0}\right)$ at the national level are made by the following dimensions: economic autonomy, time, exclusion and education. Figure 7 shows the detail for each country.

\footnotetext{
14 This is an extremely useful property for generating poverty profiles and targeting very poor groups.
}
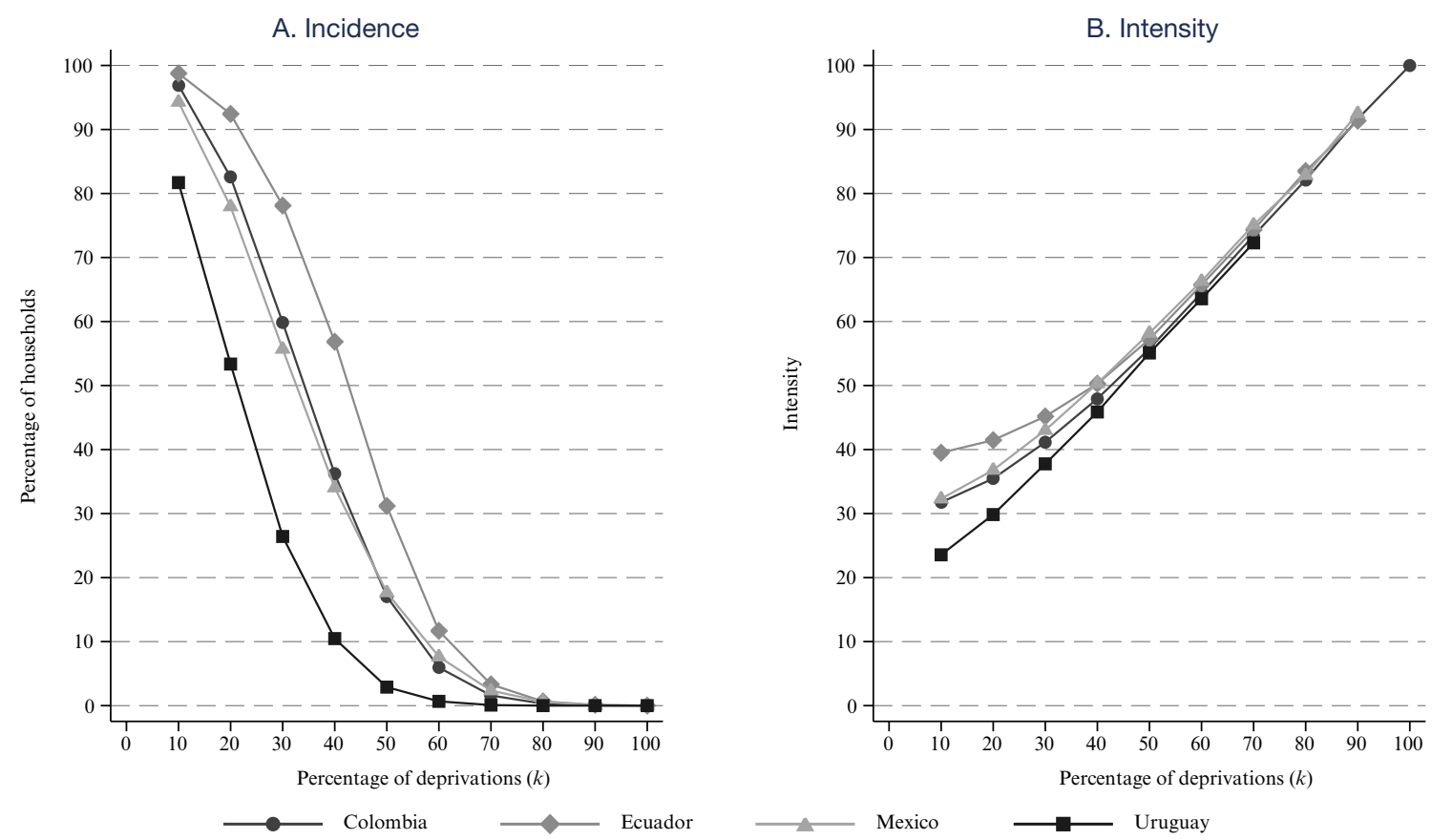

Source: Prepared by the authors, on the basis of tabulations of data from time-use surveys of Colombia (2012), Ecuador (2012), Mexico (2009) and Uruguay (2007). 
FIGURE 6

Multidimensional index (index M subindex 0)

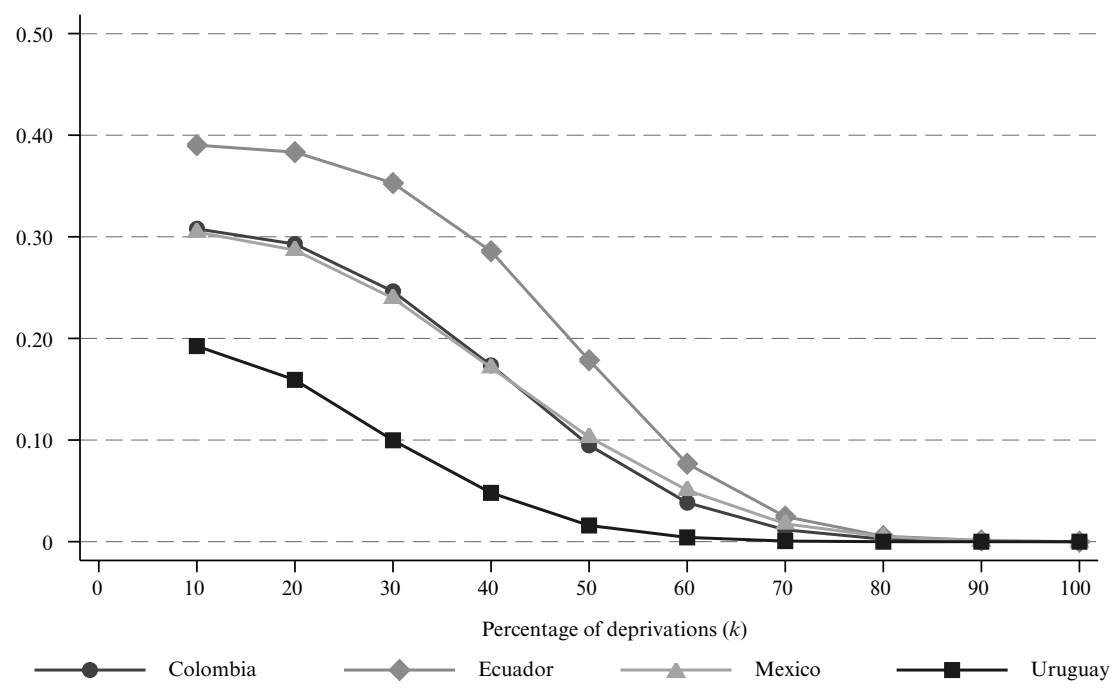

Source: Prepared by the authors, on the basis of tabulations of data from time-use surveys of Colombia (2012), Ecuador (2012), Mexico (2009) and Uruguay (2007).

FIGURE 7

Colombia, Ecuador, Mexico and Uruguay: contributions of the dimensions to the multidimensional index ( $M$ subindex 0 )

(Percentages)

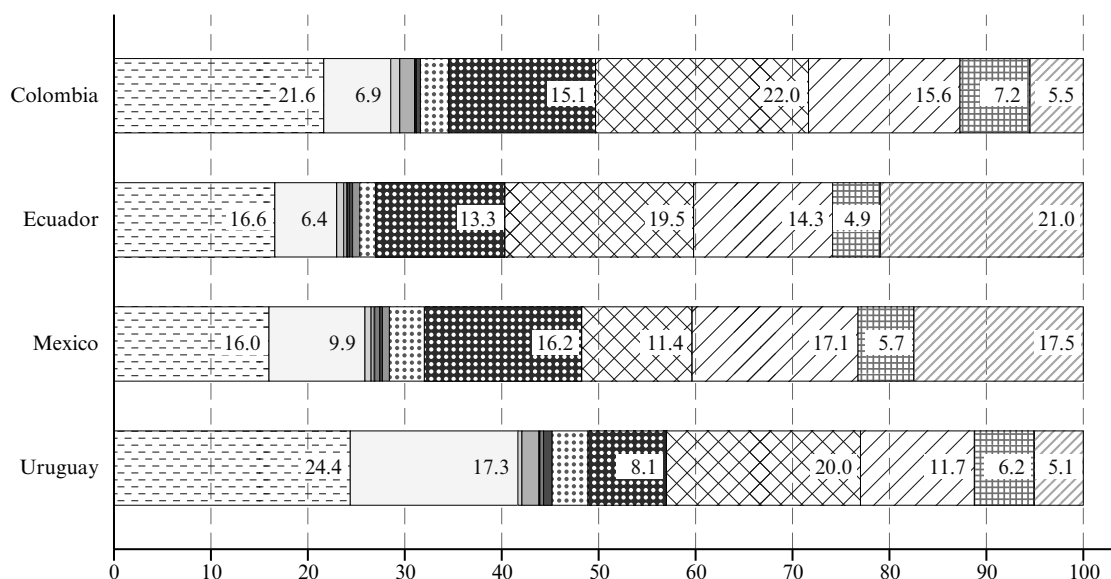

$\begin{array}{lll} & \square \text { uw } & \square \text { Water } \\ \text { Electricity } & \square \text { Fuel } & \text { Housing } \\ \text { NEET } & \text { School non-attendance } & \\ & & \end{array}$

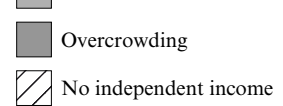

Source: Prepared by the authors, on the basis of tabulations of data from time-use surveys of Colombia (2012), Ecuador (2012), Mexico (2009) and Uruguay (2007).

Note: PW: Paid work; uw: Unpaid work; NEET: Not in education, employment or training. 


\section{Decomposition of the multidimensional index: analysis by type of household}

The multidimensional index captures different levels of deprivation by household type. Controlling by type of household, composite and extended households show a greater incidence of multidimensional poverty of time and social conditions. It is important to note that the variability in the incidence of poverty between household types moves within a range of $15 \%$ and $85 \%$ with $k=30 \%$. However, among poor households of all five types, the intensity of poverty is less variable than its incidence, with values ranging from $34 \%$ to $45 \%$, the percentages that represent average deprivations experienced by each type of household (see figure 8).

FIGURE 8

Household count ratio $(\mathrm{H})$ and intensity $(\mathrm{A})$ of poverty, by type of household (Percentages)

A. Colombia

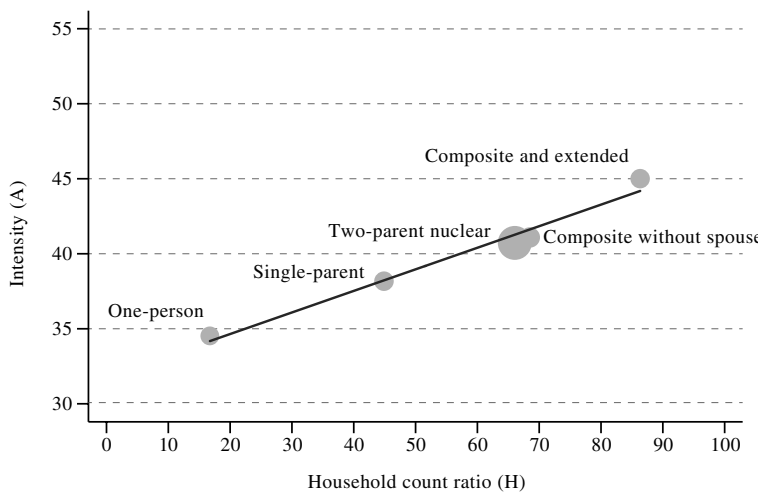

C. Mexico

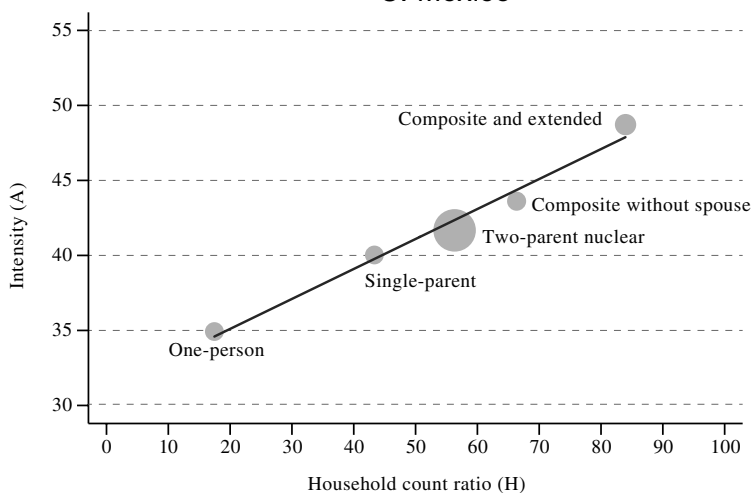

B. Ecuador

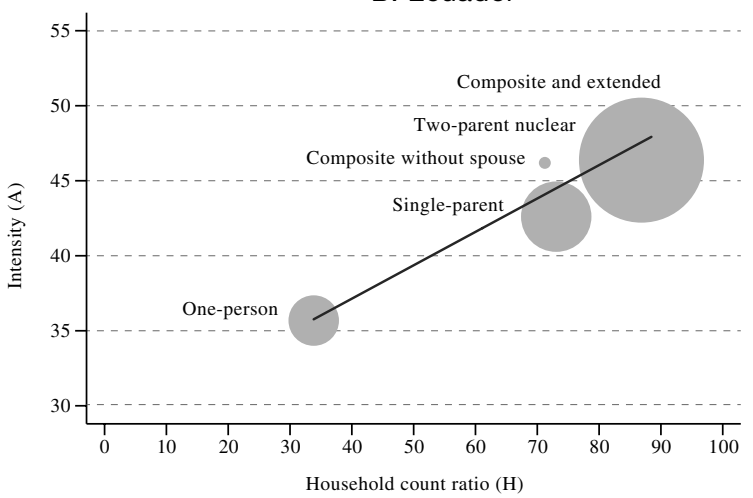

D. Uruguay

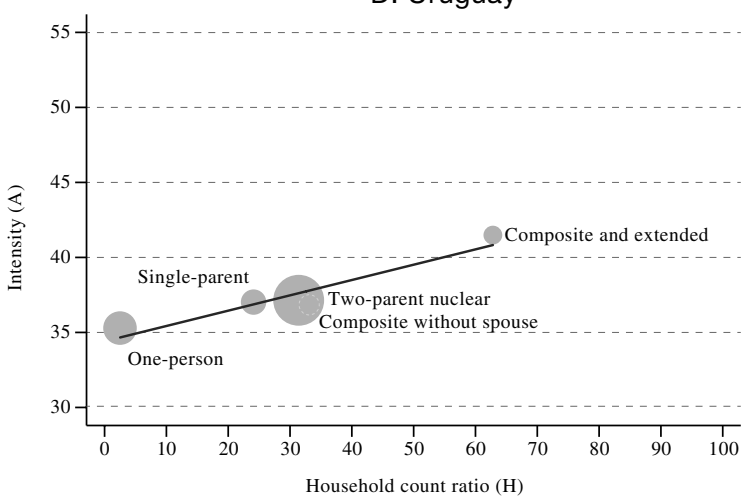

Source: Prepared by the authors, on the basis of tabulations of data from time-use surveys of Colombia (2012), Ecuador (2012), Mexico (2009) and Uruguay (2007). 
Identifying the percentage contribution by household types to the incidence and intensity of the multidimensional indexes with $k=30 \%$ shows that two-parent households contribute a greater proportion to both incidence and intensity and to $\mathrm{M}_{0}$ than other types of household (figure 9 shows the relative contribution to $\mathrm{M}_{0}$ ). This finding reveals two-parent households as those in which the sexual division of labour and its effects on deprivations in relation to time and other aspects of living conditions (housing, energy and access to water and sanitation in the household) are greater than in other types of household. One-person households are those making the smallest contributions to these variables. One argument that could explain this smaller contribution is the type of indicators involved in the time dimension, since, for example, the time indicator for unpaid caregiving and domestic work is aimed at integrating the concept of justice and the gender component in the context of a household and the allocation of time to both types of uw. Accordingly, one-person households present no deprivations in this indicator because they have no structural counterpart to visualize excessive sexual division of labour between the members.

FIGURE 9

Relative contribution of household types

(Percentages)
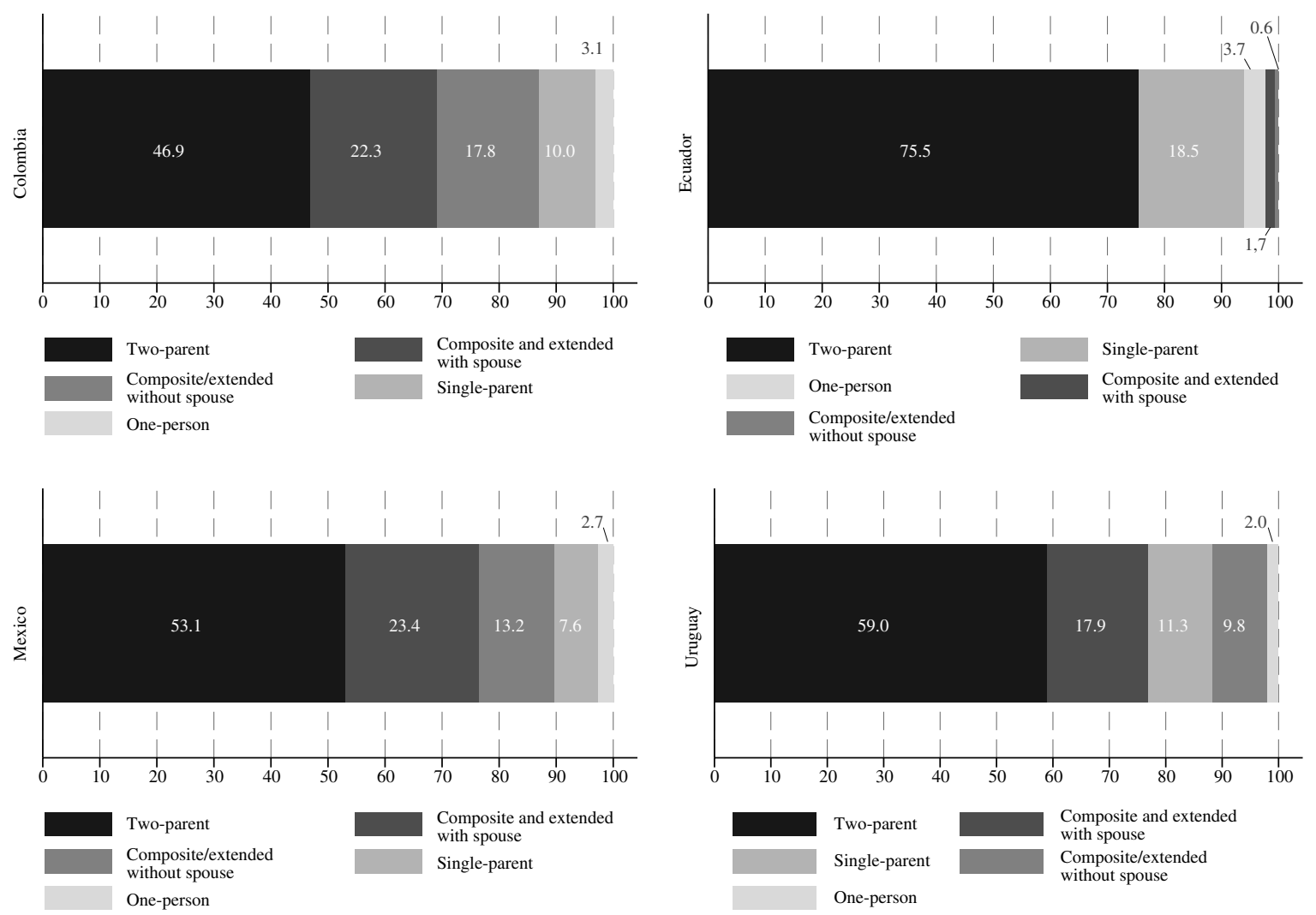

Source: Prepared by the authors, on the basis of tabulations of data from time-use surveys of Colombia (2012), Ecuador (2012), Mexico (2009) and Uruguay (2007). 


\section{V}

\section{Final remarks}

There is concern over guaranteeing women's rights and building individual, family, community and institutional capabilities to generate the spaces and opportunities for the exercise of substantive freedoms in the context of socioeconomic inequality and lack of distributive justice. Today, this concern has different connotations from those of the mid-twentieth century. Modern policy and social efforts are focused on the development of mechanisms to promote the development of human capabilities and eliminate all forms of discrimination against women.

These shifts in vision should impact on rights and the development of capabilities in four spheres. First, the delegitimization of all forms of social, cultural and economic violence that limit women's freedom to make decisions regarding the use and development of the set or combination of capabilities that they value (including capability for leisure, PW and UW). This delegitimization must also be accompanied by public policies informed by an in-depth understanding of the contexts and sectors of the female population, where social exclusion and inequalities have built up and become entrenched throughout their life cycle.

Second, efforts to identify the barriers and facilitators of human development are already present among policy-makers' objectives. However, from the point of view of human development and capacities it is crucial to identify virtuous capabilities, i.e. those that generate spaces for the development of other capabilities (Wolff and De-Shalit, 2007).

Third, the effects of the sexual division of labour on the living conditions of households and their members can be better understood from a multidimensional perspective, in which deprivations, violation of rights and exclusion mechanisms not only integrate with political power, recognition, and opportunities for agency and social justice, but also impact on the distribution and exercise of human rights. In these circumstances, access to employment by household members can produce significant changes - for better or worse - in household socioeconomic status, which can generate shifts in power dynamics within the household.

Fourth, deprivations in tangible resources (income) and intangible resources (human and social capital) shape contexts in which barriers arise to the development of capabilities for paid work and economic autonomy.
These deprivations translate into barriers to human development, because they increase the likelihood of household insecurity regarding the provision and distribution of goods, resources and recognition among their members.

Difficulties in changing the vision of these social issues are determined in part by the four spheres mentioned and have major implications for social policy aimed at increasing women's participation in the labour market. From a multidimensional and dynamic perspective, lack of distributive justice within the household and the inequity this produces are not limited to the precarious material conditions in which lower-income groups live, effective opportunities for achieving functionings or developing the capabilities that they value. Consequently, the deprivations of individuals cannot be resolved by one-dimensional programmes, but require political strategies to increase their substantive freedom through intersectoral programmes, for example. It may thus be argued that in households in which at least one member lacks economic autonomy and is also time-poor, the effects of the determinants of poverty on individual well-being are more structural than temporary. This contrasts with the assumption that time poverty is limited to particular stages of an individual's life cycle. In this context, it is fundamental to develop strategies to attack the multidimensional phenomenon of the deprivations of a household and its individuals through social programmes capable of helping to overcome these deprivations, even if only one household member is deprived in one of the factors or determinants of a decent state of living. At the same time, it is important to motivate policies aimed at eliminating discriminatory practices in households, formal and informal social institutions and the labour market.

The quest for a multidimensional vision of social policy to complement targeted strategies for eradicating income poverty must include a discussion on well-being and living conditions, not only of the proportion of the population living in poverty, but also of the vulnerable sectors (those with difficulties in consolidating a secure economic situation). Although the determinants of poverty vary in relative importance between the two groups, in both cases, for women performing PW, an overburden of Uw limits opportunities to develop other capabilities. This is evident in this article: the high 
contribution women make to the total Uw required for a household to function or to meet the caregiving needs and Uw demands of their dependants and even non-dependants.

A set of actions emerge in this article that are important for policies aimed at promoting the exercise of substantive freedoms that people value. For this, the development model must change its standard vision of minimum skills, competences and guarantees for an approach based on the development of human capabilities in Latin America.

A first challenge is to advance towards a shift in vision with respect to the determinants of well-being that have traditionally been used as proxies for living conditions, and include the impact of cumulative inequalities and tangible and intangible deprivations in the measurement of well-being. The second challenge is to advance towards a national development model on the basis of gender equality. This vision should include identifying the contribution made by the determinants of deprivations in terms of time and living conditions. This analysis may then serve as a basis for identifying patterns of convergence and divergence between the different countries. Identifying patterns will then contribute to the development of a "typology" based on models of human development and capabilities, which will support the analysis of policies on unpaid care work, distributional social justice at the household level, and on incorporating women into the labour market from a multidimensional perspective.

\section{Bibliography}

Adkins, Ch. and S. Premeaux (2012), "Spending time: the impact of hours worked on work. family conflict", Journal of Vocational Behavior, vol. 80, No. 2, Amsterdam, Elsevier.

Alkire, S. (2002), "Dimensions of human development", World Development, vol. 30, No. 2, Amsterdam, Elsevier.

Alkire, S. and J. Foster (2013), "OPHI Summer School on Multidimensional Poverty Analysis 2013", Washington, D.C., Oxford Poverty and Human Development Initiative (OPHI).

(2007), "Counting and Multidimensional Poverty Measurement", OPHI Working Paper, No. 7, Oxford, University of Oxford.

Ballet, J. and others (2014), Freedom, Responsibility and Economics of the Person, New York, Routledge.

Bardasi, E. and Q. Wodon (2009), "Working long hours and having no choice: time poverty in Guinea", Policy Research Working Paper Series, No. 4961, Washington, D.C., World Bank.

Bittman, M. and others (2005), "The time-pressure illusion: discretionary time vs. free time", Social Indicators Research, vol. 73, No. 1, Springer.

Bonke, J. and M. Browning (2003), "The distribution of well-being and income within the household", Welfare Distribution Working Paper, No. 1/2003, The Danish National Institute of Social Research.

Brighouse, H. and I. Robeyns (eds.) (2010), Measuring Justice: Primary Goods and Capabilities, Cambridge, Cambridge University Press.

Burchardt, T. (2010), "Time, income and substantive freedom: a capability approach", Time and Society, vol. 19, No. 3, SAGE.

Carrasco, C. (1991), El trabajo doméstico. Un análisis económico, Madrid, Ministry of Employment and Social Security.

Carrasco, C., C. Borderías and T. Torns (eds.) (2011), El trabajo de cuidados. Historia, teoría y políticas, Madrid, Libros de la Catarata.

Chiappori, P. and others (2011), "Are intra-household allocations policy neutral? Theory and empirical evidence", IZA Discussion Paper, No. 5594, Bonn, Institute for the Study of Labour (IZA).

Díaz, Y. (2013), "Counting Deprivations: a Household-based Multidimensional Approach" [online] http://www.ophi.org.uk/ wp-content/uploads/Present_YD_Nov2013.pdf.

Douthitt, R. (1994), “'Time to do the chores?' Factoring homeproduction needs into measures of poverty", Discussion Paper, No. 1030-94, Madison, University of Wisconsin [online] http:// www.irp.wisc.edu/publications/dps/pdfs/dp103094.pdf.
Durán, M.A. (2007), El valor del tiempo. ¿Cuántas horas te faltan al día?, Madrid, Editorial Espasa Calpe.

ECLAC (Economic Commission for Latin America and the Caribbean) (2014), Compacts for Equality: Towards a Sustainable Future (LC/G.2586(SES.35/3)), Santiago.

(2013a), Gender Equality Observatory of Latin America and the Caribbean. Annual Report 2012. A Look at Grants, Support and Burden for Women (LC/G.2561), Santiago.

(2013b), Social Panorama of Latin America 2013 (LC/G.2580), Santiago.

(2013c), Redistributing Care: The Policy Challenge (LC/G.2568-P), Coral Calderón Magaña (coord.), Santiago.

(2010a), "What kind of State? What kind of equality?" (LC/G. 2450(CRM.11/3)), Santiago.

(2010b), "Brasilia Consensus" [online] http://www.cepal. org/mujer/noticias/paginas/6/40236/consensobrasilia_ing.pdf.

Feres, J.C. and X. Mancero (2001), "Enfoques para la medición de la pobreza. Breve revisión de la literatura", Estudios Estadísticos y Prospectivos series, No. 4 (LC/L.1479-P), Santiago, Economic Commission for Latin America and the Caribbean (ECLAC).

Folbre, N. (2006), "Measuring care: gender, empowerment, and the care economy", Journal of Human Development, vol. 7, No. 2.

Fraser, N. (2009), Scales of Justice: Reimagining Political Space in a Globalizing World, New York, Columbia University Press.

Fraser, N. and A. Honneth (2006), ¿Redistribución o reconocimiento? Un debate político-filosófico, Madrid, Ediciones Morata.

Gammage, S. (2009), "Género, pobreza de tiempo y capacidades en Guatemala: un análisis multifactorial desde una perspectiva económica" (LC/MEX/L.955), Mexico City, ECLAC Subregional Headquarters in Mexico.

Goodin, R. and others (2008), Discretionary Time: A New Measure of Freedom, Cambridge, Cambridge University Press.

Gronau, R. (1977), "Leisure, home production, and work. The theory of the allocation of time revisited", The Journal of Political Economy, vol. 85, No. 6, Chicago, University of Chicago Press, December

Hobfoll, S.E. (1989), "Conservation of resources: a new attempt at conceptualizing stress", American Psychologist, vol. 44, No. 3, Washington, D.C., American Psychological Association.

ILO (International Labour Organization) (2013), 2013 Labour Overview. Latin America and the Caribbean, Lima. 
Jain, D. (2013), "Engendering economic progress", Redistributing Care: The Policy Challenge (LC/G.2568-P), Coral Calderón Magaña (coord.), Santiago.

Johnstone, M.B. (1960), How to Live Every Day of Your Life, Indianapolis, Bobbs-Merrill.

Merino, A. (2012), "La pobreza de tiempo e ingresos en Guatemala", Cuadernos de Trabajo, $\mathrm{N}^{\circ} 3$, United Nations Entity for Gender Equality and the Empowerment of Women (UN-Women).

(2010), "La pobreza multidimensional y el tiempo de las mujeres mexicanas", Cuadernos de Trabajo, No. 22, United Nations Entity for Gender Equality and the Empowerment of Women (UN-Women)/National Women's Institute.

Nussbaum, M. (2011), Creating Capabilities. The Human Development Approach, Cambridge, Massachusetts, Harvard University Press. (2003), "Capabilities as fundamental entitlements: Sen and social justice", Feminist Economics, vol. 9, No. 2-3, Taylor $\&$ Francis.

Pick, S. and J. Sirkin (2010), Breaking the Poverty Cycle: The Human Basis for Sustainable Development, New York, Oxford University Press.

Robeyns, I. (2005), "Selecting capabilities for quality of life measurement", Social Indicators Research, vol. 74, No. 1, Springer.

(2003), "Sen's capability approach and gender inequality: selecting relevant capabilities", Feminist Economics, vol. 9, No. 2-3, Taylor \& Francis.

Sen, A. (2004), "Capabilities, lists, and public reason: continuing the conversation", Feminist Economics, vol. 10, No. 3, Taylor \& Francis.
(2000), Development as Freedom, Anchor Books. (1992), Inequality Reexamined, Oxford, Oxford University Press.

Stiglitz, J.E., A. Sen and J.P. Fitoussi (2009), "Report by the Commission on the Measurement of Economic Performance and Social Progress" [online] http://www.stiglitz-sen-fitoussi. fr/documents/rapport_anglais.pdf.

UN-Women (United Nations Entity for Gender Equality and the Empowerment of Women) (n/d), "Medir el trabajo no remunerado (TNR) y el uso del tiempo (UdT): visibilizar la contribución de las mujeres a la economía y sociedad" [online] http:// www2.unwomen.org/ /media/field\%20office\%20americas/ documentos/publicaciones/contribuci\%C3\%B3n\%20mujeres. pdf? $\mathrm{v}=1 \& \mathrm{~d}=20150625 \mathrm{~T} 091450$.

Vickery, C. (1977), "The time-poor: a new look at poverty", Journal of Human Resources, vol. 12, No. 1, Wisconsin, University of Wisconsin Press.

Warren, T. (2003), "Class-and gender-based working time? Time poverty and the division of domestic labour", Sociology, vol. 37, No. 4, SAGE.

wHo (World Health Organization) (1989), Health Principles of Housing, Geneva.

Wolff, J. and A. De-Shalit (2007), Disadvantage, Oxford, Oxford University Press

Zacharias, A. (2011) "The measurement of time and income poverty", Working Paper, No. 690, Levy Economics Institute of Bard College [online] http://www.levyinstitute.org/pubs/wp_690.pdf. 